УДК 338.24

Бегун Світлана,

кандидат економічних наук, доцент, Волинський національний університет імені Лесі Українки, кафедра економіки та природокористування, м. Луцьк; ORCID ID: 0000-0003-1689-4048 e-mail: Begun.Svitlana@vnu.edu.ua

Черчик Лариса, доктор економічних наук, професор, Волинський національний університет імені Лесі Українки, завідувач кафедри менеджменту та адміністрування, м. Луцьк; ORCID ID: 0000-0002-3901-216X e-mail: cherchyk.larysa@vnu.edu.ua

https://doi.org/10.29038/2786-4618-2021-02-53-61

Лажнік Анжеліка, магістр менеджменту

м. Луцьк anzhela.nikityuk97@ukr.net

\title{
СТАТИСТИКА ТУРИСТИЧНОЇ СФЕРИ ВОЛИНСЬКОЇ ОБЛАСТІ
}

У статті розглянуто динаміку основних кількісних (кількість суб'єктів туристичної діяльності; кількість туристичних путівок, реалізованих туроператорами та турагентами; кількість туроднів за реалізованими туроператорами та турагентами туристичними путівками; чисельність туристів, обслугованих туроператорами та турагентами; розподіл туристів за метою поїздки; показники кадрового забезпечення суб'єктів туристичної діяльності) та вартісних (дохід від надання туристичних послуг, операційні витрати, вартість туристичних путівок, реалізованих туроператорами та турагентами) показників туристичної сфери Волинської області. Визначено їх частку у відповідних показниках загалом по Україні. Виявлено основні передумови, які вплинули на стан розвитку туристичної сфери за період 2015-2019 років.

Ключові слова: статистика, туризм, туристичні агенції, туристичні оператори.

Бегун Светлана, кандидат экономических наук, доцент, Волынский национальный университет имени Леси Украинки, кафедра экономики и природопользования, г. Луцк

Черчик Лариса, доктор экономических наук, профессор, Волынский национальный университет имени Леси Украинский, заведующая кафедрой менеджмента и администрирования, г. Луцк

Лажник Анжелика, магистр менеджмента, г. Луцк

\section{СТАТИСТИКА ТУРИСТИЧЕСКОЙ СФЕРЫ ВОЛЫНСКОЙ ОБЛАСТИ}

В статье рассмотрена динамика основных количественных (число субъектов туристической деятельности, количество туристических путевок, реализованных туроператорами и турагентами, количество туродней по реализованным туроператорами и турагентами путевкам, численность туристов, обслуженных туроператорами и турагентами, распределение туристов по цели поездки; показатели кадрового обеспечения субъектов туристической деятельности) и стоимостных (доход от предоставления туристических услуг, операционные 
расходы, стоимость туристических путевок, реализованных туроператорами и турагентами) показателей туристической сферы Волынской области. Определена их доля в соответствующих показателях в целом по Украине. Выявлены основные предпосылки, которые повлияли на состояние туристической сферы за период 2015-2019 годов.

Ключевые слова: статистика, туризм, туристические агентства, туристические операторы.

\author{
Begun Svitlana, \\ PhD in Economics, Associate Professor, \\ Lesya Ukrainka Volyn National University, \\ The Department of Economics and Environmental Management, \\ Lutsk \\ Cherchyk Larysa, \\ Doctor of Economics, professor Associate Professor \\ Lesya Ukrainka Volyn National University, \\ Head of Department of Management and Administration \\ Lutsk \\ Lazhnik Anzhelika, \\ Master's degree Management \\ Lesya Ukrainka Volyn National University
}

Lutsk

\title{
STATISTICS OF THE TOURIST SPHERE OF VOLYN REGION
}

The article considers the dynamics of the main quantitative and cost indicators of the tourism sector of the Volyn region. Their share in the corresponding indicators as a whole across Ukraine is defined.

The number of tourism entities in the Volyn region has increased slightly, mainly due to an increase in the number of travel agents - individuals. The number of tourist vouchers and tours sold by tour operators and travel agents has also increased, but at a much slower pace than in Ukraine. The same trend in terms of the number of tourists served by tour operators and travel agents. Most of them are residents of the Volyn region, more than 56\% of whom go abroad, more than $30 \%$ travel in Ukraine, the rest are foreign guests. The purpose of the trip for a significant part of tourists is recreation and entertainment (97\%). Indicators of staffing of tourism entities - legal entities and individuals are insignificant, 45 and 50 people, respectively.

The dynamics of the call sign growth of domestic tourism indicates the formation of the internal culture of recreation, a return to national historical and cultural traditions. In addition, the development of domestic tourism creates additional jobs, expands opportunities for self-employment, ensures the development of new areas of economic activity, contributes to the economic and social strengthening of local communities.

Despite the critical situation associated with economic crises, and now - with the pandemic and lockdown in our country and many countries, services are provided, their performance is quite high: in 2019 compared to 2015, despite a significant reduction in the number of tour operators, the number sold tourist vouchers increased, income from tourist services increased,

The main preconditions that have affected the state of the tourism sector for the period 2015-2019 have been identified: increasing risks of disease, deteriorating health of the nation; low incomes of a significant part of the population and a high level of stratification of Ukrainian society; increasing the level of urbanization, urban population, reducing safe living space; environmental pollution, deterioration of the natural environment.

Keywords: statistics, tourism, travel agencies, tour operators.

Постановка наукової проблеми та їі значення. Статистика туризму необхідна для аналізу ринку туристичних та рекреаційних послуг, обгрунтування бізнес-планів та інвестиційних проектів туристичними підприємствами, здійснення наукових досліджень. Якість виконуваних робіт багато в чому залежить від повноти й об'єктивності статистичних даних.

Туризм активно розвивається, є пріоритетною сферою економіки багатьох регіонів України, тому їі необхідно детальніше вивчати з метою виявлення проблем, перспектив розвитку. 
Аналіз останніх досліджень проблеми. Туризм відноситься до сфер діяльності, які стрімко розвиваються. На це впливають такі чинники як висока інвестиційна привабливість, прибутковість діяльності, можливість отримання валютних надходжень, невеликі інвестиції при започаткуванні діяльності; зростання потреб у відновлення здоров'я, життєвих сил, фізичного та психоемоційного, культурного розвитку.

Власні дослідження [1-3] та напрацювання вітчизняних вчених [4-13] дозволили зробити низку узагальнень та виявити сучасні тренди розвитку туристичної сфери України:

- підвищуються ризики захворювання, погіршується здоров'я нації. На це впливає багато факторів, пов'язаних з умовами та способом життя, станом довкілля, умовами праці та ії інтенсивністю, низьким рівнем доходів;

- велика частина населення має низькі доходи. Високий рівень стратифікації українського суспільства за цим критерієм породжує значні розбіжності між бажаннями, навіть нагальними потребами та можливостями українців, що негативно відображається на їх здоров”ї, показниках розвитку. Щоб реалізувати запити людей з низьким та середнім рівнем доходів, необхідно розвивати туристично-рекреаційну сферу, використовуючи ресурси та умови свого регіону, забезпечуючи ї доступність;

- зростання рівня урбанізації, чисельності міського населення, не врахування усіх аспектів формування сприятливого міського середовища часто негативно впливає на умови життя в містах, зменшення безпечного життєвого простору. Умови життя в сучасному місті 3 високою концентрацією підприємств, забрудненою атмосферою, шумом, інтенсивним пересуванням транспортних засобів підвищують чинник ризику захворюваності й ускладнюють процес відновлення сил людини. Інтенсивно забудовуються периферійні території, які використовувались для відпочинку в кінці робочого тижня, зменшуються площі скверів, парків, міських лісів, актуальні для щоденного відпочинку та у вихідні дні. При цьому потреби в таких територіях зростають;

- значне забруднення довкілля, погіршення стану природного середовища. Умови навколишнього середовища нині не просто впливають, а визначають умови суспільного виробництва (рекреаційного - особливо) та безпеку життєдіяльності загалом, а діяльність людини, у тому числі й природокористування, визначає якість навколишнього середовища.

Водночас сучасний світ ставить нові виклики, пов'язані зі зміною пріоритетів розвитку. Змінюються критерії оцінювання стану соціально-економічного розвитку, акценти функціонування соціально-економічних систем. Тому проблем лишається досить багато, вони потребують подальшого вивчення, для чого важливо розуміти тенденції розвитку туристичної сфери.

Цілі статті - на основі статистичної інформації виявити динаміку змін та основні причини, які на них вплинули.

Виклад основного матеріалу й обгрунтування отриманих результатів дослідження. Волинська область володіє значним туристичним потенціалом i вдалим територіальним розміщенням. На іiі території зосереджені туристичні та рекреаційні заклади різних типів, заклади туристичної інфраструктури, які здатні задовольнити попит власного населення та приїжджих на багато видів туристичних послуг.

Динаміка кількісних показників суб’єктів туристичної діяльності - юридичних осіб відображена у табл. 1.

Таблиия 1

Динаміка кількісних показників суб'єктів туристичної діяльності України та Волинської області (юридичні особи)

\begin{tabular}{|l|c|c|c|c|c|}
\hline \multicolumn{1}{|c|}{ Показники } & 2015 & 2016 & 2017 & 2018 & 2019 \\
\hline $\begin{array}{l}\text { Кількість суб'єктів туристичної } \\
\text { діяльності - усього, од. } \\
\text { Україна }\end{array}$ & 1785 & 1838 & 1743 & 1833 & 1867 \\
\hline Волинська область & 21 & 21 & 23 & 19 & 21 \\
\hline Волинська область, \% & 1,2 & 1,1 & 1,3 & 1,0 & 1,1 \\
\hline У тому числі & & & & & \\
\hline - туроператори & & & & & \\
\hline
\end{tabular}


Економічний часопис Волинського національного університету імені Лесі Украӥнки

\begin{tabular}{|c|c|c|c|c|c|}
\hline Україна & 500 & 552 & 498 & 529 & 538 \\
\hline Волинська область & 10 & 4 & 4 & 3 & 4 \\
\hline Волинська область, \% & 2,0 & 0,7 & 0,8 & 0,6 & 0,7 \\
\hline $\begin{array}{l}\text { - турагенти } \\
\text { Україна }\end{array}$ & 1228 & 1222 & 1172 & 1243 & 1259 \\
\hline Волинська область & 9 & 12 & 14 & 12 & 14 \\
\hline Волинська область, \% & 0,7 & 1,0 & 1,2 & 1,0 & 1,1 \\
\hline $\begin{array}{l}\text { - суб'єкти, що здійснюють екскурсійну } \\
\text { діяльність } \\
\text { Україна }\end{array}$ & 57 & 64 & 73 & 61 & 70 \\
\hline Волинська область & 2 & 5 & 5 & 4 & 3 \\
\hline Волинська область, \% & 3,5 & 7,8 & 6,9 & 6,6 & 4,3 \\
\hline $\begin{array}{l}\text { Кількість туристичних путівок, } \\
\text { реалізованих туроператорами та } \\
\text { турагентами } \\
\text { Україна }\end{array}$ & 1022896 & 1430395 & 1342947 & 2091692 & 2933680 \\
\hline Волинська область & 5036 & 14856 & 6064 & 5853 & 6904 \\
\hline Волинська область, \% & 0,5 & 1,0 & 0,5 & 0,3 & 0,2 \\
\hline $\begin{array}{l}\text { Кількість туроднів за реалізованими } \\
\text { туроператорами та турагентами } \\
\text { туристичними путівками, од. } \\
\text { Україна }\end{array}$ & 9485142 & 14917368 & 16750382 & 24790502 & 26969283 \\
\hline Волинська область & 44269 & 64275 & 54834 & 63132 & 73582 \\
\hline Волинська область, \% & 0,5 & 0,4 & 0,3 & 0,3 & 0,3 \\
\hline
\end{tabular}

Примітка. За даними джерел [14-15].

За період з 2015 по 2019 рр. загальна кількість суб’єктів туристичної діяльності в Україні зростала на 4,39 \%, зокрема, на 7,6 \% - туроператорів, на 2,2 \% - турагентів. На Волині показник не змінився - 21 од., що склало 1,1 \% від аналогічного показника по Україні. Негативною тенденцією було зменшення туроператорів, яких у 2015 р. було 10, а в 2019 - 4. В Україні кількість тургагентів за період з 2015 по 2019 рр. збільшилась з 1228 до 1259. Кількість суб'єктів, які здійснюють екскурсійну діяльність, збільшилась в Україні 357 до 70, у Волинській області у 2019 р. лишилось лише 3. Це 4,3 \% від загальної кількості по Україні.

Показники кількості реалізованих туристичних путівок то зростали, то зменшувались. Зокрема, у 2016 році їх кількість кардинально збільшилась. Потім спостерігається спад. Найбільший обсяг реалізовано у 2019 р. Показники кількості туроднів за реалізованими туристичними путівками, крім 2017 р., зростали. Якщо порівняти кількісні показники суб'єктів туристичної діяльності на Волині 3 загальними по Україні, то матимемо таку картину: по кількості реалізованих туристичних путівок юридичними особами частка області коливалась від $1 \%$ у 2016 р. до 0,2 \% у 2019; по кількості туроднів за реалізованими туристичними путівками юридичними особами частка області коливалась від $0,5 \%$ у 2015 р. до 0,3 \% у 2018.

Динаміка кількісних показників суб'єктів туристичної діяльності - фізичних осіб відображена у табл. 2.

Таблиия 2

Динаміка кількісних показників суб'єктів туристичної діяльності України та Волинської області (фізичні особи)

\begin{tabular}{|l|c|c|c|c|c|}
\hline \multicolumn{1}{|c|}{ Показники } & 2015 & 2016 & 2017 & 2018 & 2019 \\
\hline $\begin{array}{l}\text { Кількість суб'єктів туристичної } \\
\text { діяльності, усього, од } \\
\text { Україна }\end{array}$ & 1397 & 1668 & 1726 & 2460 & 2797 \\
\hline Волинська область & 47 & 48 & 43 & 55 & 75 \\
\hline
\end{tabular}


РОЗДІЛ І. Економіка. 2, 2021

\begin{tabular}{|c|c|c|c|c|c|}
\hline Волинська область, \% & 3,36 & 2,88 & 2,49 & 2,23 & 2,68 \\
\hline $\begin{array}{l}\text { У тому числі } \\
\text { - турагенти } \\
\text { Україна }\end{array}$ & 1319 & 1581 & 1630 & 2322 & 2644 \\
\hline Волинська область & 44 & 44 & 39 & 51 & 71 \\
\hline Волинська область, \% & 3,34 & 2,78 & 2,39 & 2,20 & 2,69 \\
\hline $\begin{array}{l}\text { - суб'єкти, що здійснюють } \\
\text { екскурсійну діяльність } \\
\text { Україна }\end{array}$ & 78 & 87 & 96 & 138 & 153 \\
\hline Волинська область & 3 & 4 & 4 & 4 & 4 \\
\hline Волинська область, \% & 3,85 & 4,60 & 4,17 & 2,90 & 2,61 \\
\hline $\begin{array}{l}\text { Кількість } \quad \text { реалізованих } \\
\text { туристичних путівок, од. } \\
\text { Україна }\end{array}$ & 129249 & 181607 & 225998 & 314447 & 411492 \\
\hline Волинська область & 4684 & 6860 & 5364 & 6220 & 8645 \\
\hline Волинська область, \% & 3,62 & 3,78 & 2,37 & 1,98 & 2,10 \\
\hline $\begin{array}{lr}\text { Кількість } & \text { туроднів } \\
\text { реалізованими } & \text { туристичними } \\
\text { путівками, од. } & \\
\text { Україна } & \end{array}$ & 1394061 & 2088380 & 2927350 & 4285695 & 5325752 \\
\hline Волинська область & 43289 & 60666 & 65809 & 81110 & 137940 \\
\hline Волинська область, \% & 3,10 & 2,90 & 2,25 & 1,90 & 2,60 \\
\hline
\end{tabular}

За період з 2015 по 2019 р. загальна кількість суб’єктів туристичної - фізичних осіб зростала в Україні з 1397 до 2797, на Волині з 47 до 75, тобто 2,68 \% від загальноукраїнського. Це турагенти, які активізували свою діяльність через зменшення туроператорів. Тому показники кількості реалізованих туристичних путівок суттєво зростали: більше, ніж в 3 рази по Україні, вдвічі у Волинській області. Кількість туроднів за реалізованими туристичними путівками теж зросла: на 3,9 млн по Україні та на 94,7 тис по Волинській області.

Якщо порівняти кількісні показники суб'єктів туристичної діяльності, що мають форму юридичної особи та фізичних осіб-підприємців, то у 2019 р. питома вага фізичних осіб-підприємців склала майже на 33 \% більше, ніж юридичних осіб.

Чисельність туристів, обслугованих туроператорами та турагентами відображено у табл. 3.

Таблиия 3

Динаміка чисельності туристів, обслугованих туроператорами та турагентами по Україні та

Волинській області, осіб

\begin{tabular}{|l|c|c|c|c|c|}
\hline Показники & 2015 & 2016 & 2017 & 2018 & 2019 \\
\hline Юридичні особи & & & & & \\
\hline $\begin{array}{l}\text { Кількість туристів, обслугованих } \\
\text { туроператорами та турагентами, } \\
\text { Усього Україна }\end{array}$ & 1814827 & 2250107 & 2403987 & 3957623 & 5319952 \\
\hline Волинська область & 8552 & 16525 & 7502 & 9513 & 9247 \\
\hline Волинська область, \% & 0,8 & 0,7 & 0,3 & 0,2 & 0,2 \\
\hline $\begin{array}{l}\text { громадян України } \\
\text { Україна }\end{array}$ & 1800277 & 2216323 & 2365424 & 3884682 & 5236249 \\
\hline Волинська область & 8005 & 16098 & 6931 & 9085 & 8773 \\
\hline Волинська область, \% & 0,4 & 0,7 & 0,3 & 0,2 & 0,2 \\
\hline $\begin{array}{l}\text { в межах території України } \\
\text { Україна }\end{array}$ & 301865 & 375091 & 393396 & 376569 & 449655 \\
\hline Волинська область & 2468 & 1461 & 1388 & 3251 & 1095 \\
\hline Волинська область, \% & 0,8 & 0,4 & 0,4 & 0,9 & 0,2 \\
\hline
\end{tabular}


Економічний часопис Волинського національного університету імені Лесі Украӥнки

\begin{tabular}{|l|c|c|c|c|c|}
\hline за кордоном & 1498412 & 1841232 & 1972028 & 3508113 & 4786594 \\
\hline Україна & 5537 & 14637 & 5543 & 5834 & 7678 \\
\hline Волинська область & 0,4 & 0,8 & 0,3 & 0,2 & 0,2 \\
\hline Волинська область, \% & 14550 & 33784 & 38563 & 72941 & 83703 \\
\hline $\begin{array}{l}\text { Іноземців } \\
\text { Україна }\end{array}$ & 547 & 427 & 571 & 428 & 474 \\
\hline Волинська область & 3,8 & 1,3 & 1,5 & 0,6 & 0,6 \\
\hline Волинська область, \% & & & & & \\
\hline Фізичні особи & & & & \\
\hline $\begin{array}{l}\text { Кількість туристів, обслугованих } \\
\text { туроператорами та турагентами - Усього } \\
\text { Україна }\end{array}$ & 204749 & 299499 & 402439 & 599824 & 812145 \\
\hline Волинська область & 7068 & 10001 & 9545 & 12294 & 18156 \\
\hline Волинська область, \% & 3,5 & 3,4 & 2,4 & 2,1 & 2,2 \\
\hline $\begin{array}{l}\text { громадян України } \\
\text { Україна }\end{array}$ & 204140 & 298212 & 401397 & 596820 & 809008 \\
\hline Волинська область & 6970 & 9942 & 9437 & 12274 & 18074 \\
\hline Волинська область, \% & 3,4 & 3,3 & 2,4 & 2,1 & 2,2 \\
\hline $\begin{array}{l}\text { в межах території України } \\
\text { Україна }\end{array}$ & 55162 & 78470 & 83571 & 80230 & 70736 \\
\hline Волинська область & 3180 & 5133 & 2551 & 2712 & 2117 \\
\hline Волинська область, \% & 5,8 & 6,5 & 3,1 & 3,4 & 3,0 \\
\hline $\begin{array}{l}\text { за кордоном } \\
\text { Україна }\end{array}$ & 148978 & 219742 & 317826 & 516590 & 738272 \\
\hline Волинська область & 3790 & 4809 & 6886 & 9562 & 15957 \\
\hline Волинська область, \% & 2,54 & 2,19 & 2,17 & 1,85 & 2,16 \\
\hline $\begin{array}{l}\text { Іноземців } \\
\text { Україна }\end{array}$ & 609 & 1287 & 1042 & 3004 & 3137 \\
\hline Волинська область & 98 & 59 & 108 & 20 & 82 \\
\hline Волинська область, \% & 4,6 & 10,4 & 0,7 & 2,6 \\
\hline
\end{tabular}

Примітка. За даними джерел [14-15].

Кількість туристів, обслугованих туристичними закладами у Волинській області зростала, зокрема: туроператорами та турагентами юридичними особами на 8 \% (в Україні - в 2,9 рази); туроператорами та турагентами фізичними особами в 2,6 рази (в Україні - в 4 рази).

За структурою обслуговуваних осіб домінує виїзний туризм, його показники зростали з року в рік, проте частка від загального показника по Україні мізерна, до того ж, крім 2016 р., зменшується до $0,2 \%$. За метою поїздки - це дозвілля та відпочинок.

Іноземних туристів зовсім мало, їх частка від загального показника по Україні незначна, до того ж зменшується від 3,8 \% до 0,6 \% у турфірм - юридичних осіб (основна мета - лікування (по роках від $21 \%$ до $6 \%$ )), від $11,7 \%$ до 0,7 \% у фізичних осіб (основна мета - відпочинок і дозвілля).

Обсяги внутрішніх туристів сягають третини-чверті усіх. Найбільший показник по організації дозвілля та відпочинку: від 3,3 до 8,5\%.

Розподіл туристів, обслугованих туроператорами та турагентами, за метою поїздки (табл. 4).

Таблиия 4

Розподіл туристів за метою поїздки (юридичні особи / фізичні особи) по Україні та Волинській області за 2015-2019 рр., осіб

\begin{tabular}{|l|c|c|c|c|c|}
\hline \multicolumn{1}{|c|}{ Показники } & 2015 & 2016 & 2017 & 2018 & 2019 \\
\hline Україна & & & & & \\
\hline Туристів, усього, & $1814827 /$ & $2250107 /$ & $2403987 /$ & $3957623 /$ & $5319952 /$ \\
у т.ч. & 204749 & 299499 & 402439 & 3957623 & 812145 \\
\hline службова, ділова, навчання & $178832 /$ & $176230 /$ & $194977 /$ & $211794 /$ & $267513 /$ \\
\hline
\end{tabular}


РОЗДІЛ І. Економіка. 2, 2021

\begin{tabular}{|l|c|c|c|c|c|}
\hline & 4824 & 4670 & 2379 & 5090 & 3658 \\
\hline дозвілля, відпочинок & $1510668 /$ & $1902900 /$ & $2143615 /$ & $3671415 /$ & $4963974 /$ \\
& 192272 & 276973 & 373450 & 574762 & 797671 \\
\hline лікування & $29865 /$ & $79412 /$ & $54661 /$ & $61303 /$ & $55998 /$ \\
& 6574 & 16472 & 24638 & 19003 & 9931 \\
\hline спортивний туризм & $2019 / 837$ & $2982 / 774$ & $2593 / 271$ & $3352 / 387$ & $3953 / 293$ \\
\hline спеціалізований туризм & $1174 / 51$ & $768 / 50$ & $1841 / 611$ & $1821 / 155$ & $21332 / 197$ \\
\hline Волинська область & & & & & \\
\hline Туристів, усього, у т.ч. & $8552 /$ & $16525 /$ & $7502 /$ & $9513 /$ & $9247 /$ \\
& 7068 & 10001 & 9545 & 9513 & 18156 \\
\hline службова, ділова, навчання & $23 / 75$ & $6 / 24$ & $130 / 44$ & $83 / 58$ & $14 / 142$ \\
\hline дозвілля, відпочинок & $7680 / 6985$ & $15648 / 9793$ & $6331 / 9427$ & $8936 / 12103$ & $8710 / 17957$ \\
\hline лікування & $849 / 39$ & $871 / 66$ & $816 / 74$ & $344 / 129$ & $345 / 54$ \\
\hline спортивний туризм & - & $-/ 118$ & $225 /-$ & $150 / 4$ & $148 /-$ \\
\hline
\end{tabular}

Примітка. За даними джерел [14-15].

Як зазначалось, значна частка обслуговуваних припадає на підприємства - юридичні особи, крім 2017 р.. Вони лідирували, надаючи послуги в організації лікування, у 2015, 2016, 2019 pр. - дозвілля та відпочинку. Динаміка позивного росту внутрішнього туризму свідчить про формування внутрішньо-національної культури відпочинку, свідомого ставлення до природних ресурсів та поверненням до національних історико-культурних традицій. Крім того, розвиток внутрішнього туризму формує додаткові робочі місця, розширює осередки внутрішньо-туристичної сфери, забезпечує розвиток нових векторів ведення господарської діяльності у цій царині національного господарства, сприяє економіко-соціальному зміцненню місцевих громад.

Проаналізуємо вартісні показники туристичної сфери Волинської області (табл. 5).

Динаміка вартісних показників суб'сктів туристичної діяльності Волинської області

Таблиия 5 (юридичних та фізичних осіб) за 2015-2019 pp.

\begin{tabular}{|c|c|c|c|c|c|}
\hline Показники & 2015 & 2016 & 2017 & 2018 & 2019 \\
\hline \multicolumn{6}{|c|}{ Юридичні особи } \\
\hline $\begin{array}{l}\text { Дохід від надання туристичних послуг } \\
\text { (без ПДВ, акцизів), тис грн }\end{array}$ & 9427,5 & 12395,4 & 18803,3 & 15339,5 & 19476,6 \\
\hline Операційні витрати, тис грн & 2570,0 & 6139,9 & 5171,6 & 4433,1 & 5561,5 \\
\hline $\begin{array}{l}\text { Вартість туристичних путівок, } \\
\text { реалізованих туроператорами та тур } \\
\text { агентами, тис грн }\end{array}$ & 35004,5 & 70476,6 & 59045,6 & 74530,5 & 101766,7 \\
\hline \multicolumn{6}{|c|}{ Фізичні особи } \\
\hline $\begin{array}{l}\text { Дохід від надання туристичних послуг } \\
\text { (без ПДВ, акцизів), тис грн }\end{array}$ & 4807,8 & 5961 & 7127,8 & 8280,6 & 13724,2 \\
\hline $\begin{array}{l}\text { Вартість реалізованих туристичних } \\
\text { путівок, тис грн }\end{array}$ & 49576,0 & 63422,7 & 89585,2 & 131488 & 209691,4 \\
\hline
\end{tabular}

Примітка. За даними джерел [14-15].

Дохід від надання туристичних послуг у період з 2015 по 2019 роки збільшувався, при цьому темпи його росту були більшими, ніж операційних витрат, які теж зростали. Ця тенденція однакова як для фізичних, так і юридичних осіб. Це пов'язано з збільшенням кількості проданих туристичних путівок та їх вартості, що $є$ беззаперечним показником росту прибутку як для суб'єктів підприємницької діяльності, так і для галузі туризму загалом.

Вартість туристичних путівок, реалізованих туроператорами та турагентами також росла більш ніж в чотири рази. 
Висновки та перспективи подальших досліджень. Результати статистичного дослідження свідчать, що туризм $є$ важливою складовою економіки регіону та країни загалом. Його основне завдання - забезпечення туристичних та рекреаційних потреб у необхідній кількості та високої якості. Незважаючи на критичний стан, пов'язаний з економічними кризами, а зараз - 3 пандемією i локдауном, послуги надаються, їх показники достатньо високі: у 2019 р. порівняно з 2015, попри значне зменшення кількості туроператорів, кількість туристичних путівок, реалізованих туроператорами та турагентами, юридичними особами, збільшилась на 1800 одиниць, фізичними особами - на 3961 од., їх вартість - на 227 млн грн. Дохід від надання туристичних послуг зріс на 19 млн грн. Негативною тенденцією є значне переважання виїзного туризму над внутрішнім і в'їзним. Для туристичних бізнес-структур характерні високий рівень трудомісткості, проте на Волині ці показники невисокі, чисельність персоналу за 5 років зменшилась в фірмах - юридичних особах, проте зросла чисельність фізичних осіб. Виявлено низький рівень забезпечення персоналом 3 відповідною вищою освітою.

Водночас, наявні певні недоліки та неточності, які потребують вирішення та вдосконалення. У статистичній практиці було б доцільно запровадити вибіркові статистичні обстеження туристичної сфери, які дали б змогу отримувати попередні дані про іiї стан та розвиток, а у звітності - додатково ввести такі показники, як чисельність одноденних туристів, кількість обслугованих пенсіонерів, обсяг об'єктів на основі яких було надано туристичні послуги.

На нашу думку, вище наведені пропозиції дозволять певною мірою вдосконалити статистичне забезпечення туристично-рекреаційної сфери на регіональному рівні.

\section{Джерела та література}

1. Черчик Л., Єрко І., Коленда Н., Міщенко О. Сучасний стан розвитку туристично-рекреаційного комплексу Волинської області : монографія. Луцьк : Східноєвропейський національний університет імені Лесі Українки, 2014. 152 с.

2. Черчик Л., Міщенко О., Єрко І. Туристично-рекреаційний комплекс Волинської області: передумови формування : монографія. Луцьк : Східноєвропейський національний університет імені Лесі Українки, 2014. $128 \mathrm{c}$.

3. Черчик Л. М., Бегун С. І. Статистичне дослідження рівня забезпечення закладами розміщення туристично-рекреаційної сфери західних регіонів України. Науковий вісник Східноєвропейського національного університету імені Лесі Українки. Серія: Економічні науки. 2013. № 4 (231). С. 146-152.

4. Перспективи розвитку туризму в Україні та світі: управління, технології, моделі: колективна монографія. Видання п'яте / за наук. ред. проф. Матвійчук Л.Ю. Луцьк: IBВ Луцького НТУ, 2019. 320 с.

5. Марценюк Л. В. Проблеми та перспективи розвитку туризму в Україні. Economics Bulletin, 2015, № 3. C. $76-82$.

6. Андрєєва Г.П., Коваль П.Ф. Теоретичні засади спеціалізованого туризму. Глобальні та нащуіональні проблеми економіки. 2015. № 7. URL: http://www.global-national.in.ua.

7. Антонюк В.П. Рекреаційно-туристична сфера України як чинник людського розвитку. Збірник наукових праць Таврійського державного агротехнологічного університету (економічні науки). 2015. № 1(29). C. $146-152$.

8. Корнацький В.М. Проблеми здоров’я та подовження тривалості життя населення України. Наукові дискусії. 2008. № 5 (67). URL: https://www.umj.com.ua/article/2596/problemi-zdorov-ya-ta-podovzhennya-trivalostizhittya-naselennya-ukraini

9. Котенко Т.М., Каленюк І.С. Соціальні аспекти розвитку рекреації і туризму як значущого сегменту світового господарства: теоретико-методологічні засади. Науковий вісник УжНУ. 2015. Вип. 3. С. 172-176.

10. Людський розвиток в Україні: історичний вимір трансформації державної соціальної політики : монографія / за ред. Е.М. Лібанової. К. : Ін-т демографії та соціальних досліджень ім. М.В. Птухи НАН України, 2014. 380с.

11. Мезенцева Н.І., Батиченко С.П., Мезенцев К.В. Захворюваність і здоров'я населення в Україні: суспільно-географічний вимір: Монографія. К.: ДП «Прінт Сервіс», 2018. 136 с.

12. Нездоймінов С.Г. Туризм як фактор регіонального розвитку: методологічний аспект та практичний досвід : монографія. О. : Астропринт, 2009. 304 с.

13. Ткаченко T.І. Сталий розвиток туризму: теорія, методологія, реалії бізнесу : монографія. К. : Київський національний торговельно-економічний університет, 2009. 463 с. 
14. Офіційний сайт Головного управління статистики у Волинській області URL: http://www.lutsk.ukrstat.gov.ua/ (дата звернення 07.06.2021 p.).

15. Офіційний сайт Державної служби статистики України URL: http:// www.ukrstat.gov.ua/ (дата звернення 07.06.2021р.).

\section{References}

1. Cherchyk L., Yerko I., Kolenda N., Mishchenko O. (2014). Suchasnyi stan rozvytku turystychnorekreatsiinoho kompleksu Volynskoi oblasti : Monohrafiia. [The current state of development of the tourist and recreational complex of the Volyn region: Monograph.]. Lutsk : Skhidnoievropeiskyi natsionalnyi universytet imeni Lesi Ukrainky - Lutsk: Lesia Ukrainka East European National University, 152 p. [in Ukrainian].

2. Cherchyk L., Mishchenko O., Yerko I. (2014). Turystychno-rekreatsiinyi kompleks Volynskoi oblasti: peredumovy formuvannia : Monohrafiia. [Tourist and recreational complex of Volyn region: preconditions of formation: Monograph.]. Lutsk : Skhidnoievropeiskyi natsionalnyi universytet imeni Lesi Ukrainky - Lutsk: Lesia Ukrainka East European National University, 128p. [in Ukrainian].

3. Cherchyk L. M., Begun S. I. (2013). Statystychne doslidzhennia rivnia zabezpechennia zakladamy rozmishchennia turystychno-rekreatsiinoi sfery zakhidnykh rehioniv Ukrainy. [Statistical research level of accommodation facilities of tourist and recreation areas western Ukraine]. Naukovyi visnyk Skhidnoievropeiskoho natsionalnoho universytetu imeni Lesi Ukrainky. Seriia: Ekonomichni nauky. Lutsk : SNU imeni Lesi Ukrainky Scientific Bulletin of the Lesia Ukrainka East European National University. Series: Economic Sciences, 4 (231). P. 146-152. [in Ukrainian].

4. Perspektyvy rozvytku turyzmu v Ukraini ta sviti: upravlinnia, tekhnolohii, modeli: kolektyvna monohrafiia.(2019). [Prospects for tourism development in Ukraine and the world: management, technology, models: Collective monograph.] Vydannia p‘yate / za nauk. red. prof. Matviichuk L.Yu. - Fifth Edition / Science. ed. prof. Matviychuk L.Y. Lutsk: IVV Lutskoho NTU- Lutsk: IVV Lutsk NTU, 320 p. [in Ukrainian].

5. Martseniuk L. V. (2015). Problemy ta perspektyvy rozvytku turyzmu v Ukraini. [Problems and prospects of tourism development in Ukraine]. Economics Bulletin, 3. P. 76-82. [in Ukrainian].

6. Andrieieva H.P., Koval P.F. (2015). Teoretychni zasady spetsializovanoho turyzmu. [Theoretical principles of specialized tourism]. Hlobalni ta natsionalni problemy ekonomiky - Global and national economic problems, 7. Retrieved from: http://www.global-national.in.ua. [in Ukrainian].

7. Antoniuk V.P. (2015). Rekreatsiino-turystychna sfera Ukrainy yak chynnyk liudskoho rozvytku. [Recreational and tourist sphere of Ukraine as a factor of human development]. Zbirnyk naukovykh prats Tavriiskoho derzhavnoho ahrotekhnolohichnoho universytetu (ekonomichni nauky) - Collection of scientific works of the Tavriya State Agrotechnological University (economic sciences), 1(29). P. 146-152. [in Ukrainian].

8. Kornatskyi V.M. (2008). Problemy zdorovia ta podovzhennia tryvalosti zhyttia naselennia Ukrainy. [Health problems and life expectancy in Ukraine] Naukovi dyskusii - Scientific discussions. 5 (67). Retrieved from: https://www.umj.com.ua/article/2596/problemi-zdorov-ya-ta-podovzhennya-trivalosti-zhittya-naselennya-ukraini [in Ukrainian].

9. Kotenko T.M., Kaleniuk I.S. (2015). Sotsialni aspekty rozvytku rekreatsii i turyzmu yak znachushchoho sehmentu svitovoho hospodarstva: teoretyko-metodolohichni zasady. [Social aspects of recreation and tourism development as a significant segment of the world economy: theoretical and methodological principles]. Naukovyi visnyk UzhNU - Scientific Bulletin of Uzhhorod National University. Vyp. 3. P. 172-176. [in Ukrainian].

10. Liudskyi rozvytok v Ukraini: istorychnyi vymir transformatsii derzhavnoi sotsialnoi polityky : monohrafiia / za red. E.M. Libanovoi. [Human development in Ukraine: a historical dimension of the transformation of state social policy: Monograph / ed. E.M. Lebanon]. (2014). K. : In-t demohrafii ta sotsialnykh doslidzhen im. M.V. Ptukhy NAN Ukrainy - K :: Institute of Demography and Social Research M.V. Ptukhy of the NAS of Ukraine, 380 p. [in Ukrainian].

11. Mezentseva N.I., Batychenko S.P., Mezentsev K.V. (2018). Zakhvoriuvanist i zdorovia naselennia v Ukraini: suspilno-heohrafichnyi vymir: Monohrafiia. [Morbidity and health of the population in Ukraine: socio-geographical dimension: Monograph.]. K.: DP «Print Servis» - K.: SE "Print Service", 136 p. [in Ukrainian].

12. Nezdoiminov S.H. (2009). Turyzm yak faktor rehionalnoho rozvytku: metodolohichnyi aspekt ta praktychnyi dosvid : monohrafiia. [Tourism as a factor of regional development: methodological aspect and practical experience: Monograph.]. O. : Astroprynt - A .: Astroprint, 304 p. [in Ukrainian].

13. Tkachenko T.I. (2009). Stalyi rozvytok turyzmu: teoriia, metodolohiia, realii biznesu : monohrafiia. [Sustainable development of tourism: theory, methodology, business realities: Monograph.]. K. : Kyivskyi natsionalnyi torhovelno-ekonomichnyi universytet - K .: Kyiv National University of Trade and Economics, 463 p. [in Ukrainian].

14. Ofitsiinyi sait Holovnoho upravlinnia statystyky u Volynskii oblasti. Retrieved from: http://www.lutsk.ukrstat.gov.ua/

15. Ofitsiinyi sait Derzhavnoi sluzhby statystyky Ukrainy. Retrieved from: http:// www.ukrstat.gov.ua/ 